\title{
She's my girl - male accessory gland products and their function in the reproductive biology of social bees ${ }^{1}$
}

\author{
Nínive Aguiar COLONELLO ${ }^{\mathrm{a}}$, Klaus HARTFELDER ${ }^{\mathrm{b} *}$ \\ a Faculdade de Filosofia, Ciências e Letras de Ribeirão Preto Universidade de São Paulo, Ribeirão Preto, SP, \\ b Faculdade de Medicina de Ribeirão Preto, Universidade de São Paulo, Ribeirão Preto, SP, 14040-900, Brazil
}

Received 18 October 2004 - Revised 8 December 2004 - Accepted 10 December 2004

Published online 1 June 2005

\begin{abstract}
Male accessory gland products have become a major issue in insect reproduction. They are a means of transport for sperm and can form a mating plug, and also have specific compounds that can modify the behavior and physiology of mated females. We briefly review the structure and function of accessory gland products in insects, especially in the fruitfly and some orthopterans and lepidopterans, and draw parallels to what is currently known in social bees. The structure of the mating sign differs considerably in this group. In bumble bees it consists of a viscous mass of a dipeptide and fatty acids, with linoleic acid affecting female behavior. The honey bees show considerable species-specific variation in their mating signs. In the cavity-dwelling species it is the mucus gland which provides the mass of the mating sign, and this glands undergoes a hormonally controlled sexual maturation in its program of protein synthesis. The stingless bees lack mucus glands altogether, and their mating sign consists of the ruptured genital capsule of the male. We discuss the structure of the mating sign and of its components in relation to the mating and reproductive biology of these groups of highly eusocial bees.
\end{abstract}

honeybee / bumblebee / Meliponini / reproductive tract / mating sign / Apis / Bombus

\section{MALE ACCESSORY GLAND (MAG) PRODUCTS AND THEIR FUNCTION IN INSECT REPRODUCTIVE BIOLOGY - A BRIEF OVERVIEW}

Terrestrial arthropods transfer sperm either via a spermatophore or by internal insemination. In both cases, the accessory glands of the male reproductive tract contribute a wide spectrum of compounds to spermatophores or seminal fluid. These glands are mainly mesadenes, that is, they are embryologically derived from the mesodermal duct descending from the testes. In the higher Diptera, the accessory glands of the male reproductive tract are ectadenes, representing enlarged glandular portions of the ectodermal ejaculatory duct (Leopold, 1976).
The principal secretory products of these glands in male insects are proteins, carbohydrates and lipids (Gillott, 2003). In addition, they may contain a variety of other biologically active components, such as prostaglandins in Lepidoptera (Gillott, 1988), juvenile hormone (JH) in the moth Hyalophora cecropia (Shirk et al., 1980) and possibly also in some mosquitoes (Borovsky et al., 1994), and toxic compounds that have been suggested to serve as egg protectants (Blum and Hilker, 2002; Eisner et al., 2002).

A wide range of functions has been ascribed to accessory glands products. Structural proteins are important in spermatophore formation and in the coagulation of seminal fluid within the female reproductive tract to form a mating plug. In bees, the drone leaves a mating sign in

* Corresponding author: khartfel@ rge.fmrp.usp.br

${ }^{1}$ Manuscript editor: Gudrun Koeniger 
the queen's genital chamber (Woyke, 1956). This mating sign consists of part of the drone's endophallus together with coagulating mucus and yellowish secretions of the cornual glands (Koeniger and Koeniger, 2000).

The synthesis of these compounds of different biochemical nature and their production in the different glands associated with the male reproductive tract requires coordination with spermatogenesis and sperm maturation in order to guarantee successful matings. Not surprisingly, therefore, hormones, especially $\mathrm{JH}$ and ecdysteroids, have been shown to play a role in sexual maturation and accessory gland activity in a number of insect species (Happ, 1992; Ismail and Gillot, 1995; Gillot, 1996), including the honey bee For the honey bee, we could recently show that especially ecdysteroids are potent modulators of protein synthesis in the mucus glands during sexual maturation (Colonello and Hartfelder, 2003).

\subsection{Mating plugs - from mechanical to physiological manipulation}

Male insects use a variety of strategies to guarantee that they are the exclusive sire to the offspring produced by females. Post-copulatory mate guarding until she lays eggs certainly is the most efficient one, yet it entails a high energy investment for the male to fight off other males that approach a receptive female. Evidently, such a strategy also should decrease the male's chances to find another mate during the time of mate guarding. To lower these costs, males of many species have taken to leave a mating plug in the female's genitalia to physically prevent her from mating with other males. Such a strategy is, however, far from safe, as selection should favor males that are capable of removing such a plug, and consequently, it should trigger a race for ever more efficient plugs and ever more efficient removal. In addition, for the next and especially for the last mating male it is not only the removal of the mating plug that is important but also the displacement of the sperm deposited by his predecessors.

This "red queen" deadlock appears to have been circumvented once males added components to the mating plug that are capable of manipulating female postcopulatory behavior and physiology. Such substances lower a female's receptiveness and drive her physio- logically into egg laying, with the consequence that she will exclusively use the sperm stored from the preceding mating event. Termed "tokens of love" (Wolfner, 1997), biologically active male accessory gland (MAG) products indeed appear to be a rather widespread phenomenon in the mating biology of insects, and in most cases they are produced by the accessory glands of the male reproductive tract. Their extraordinary activity was demonstrated in many experimental designs, starting with accessory gland implantation or injection of crude extracts of gland secretions into virgin females (Davey, 1965; Pickford et al., 1969; Friedel and Gillott, 1976; Morrison et al., 1982; Chen et al., 1988).

Drosophila is the long-time champion in such studies on the nature and role of MAG products (Chen and Bühler, 1970). Seminal fluid transferred by males mediates in the female physiological and behavioral changes which are beneficial to male fitness, such as reducing receptivity, stimulating oogenesis and oviposition, and enhancing sperm viability (Chapman, 2001). In addition, some MAG compounds may even be harmful to females and shorten their life span. The final molecular characterization of MAG proteins was achieved in assays utilizing mutant flies or lineages that were transgenic for specific accessory gland proteins (Acps). Such assays showed that the decrease in female receptivity and the increase in oviposition rate are transient behavioral and physiological changes, and that the persistence of high egg-laying rates requires the actual presence of sperm in the female's spermatheca (Kalb et al., 1993).

Many of the fruitfly accessory gland proteins (Acps), such as Acp26Aa, Acp36DE and Acp62F are now sequenced and have had their function identified (Wolfner et al., 1997). However, it is the 36 residue Acp70A (sex peptide) that has received most attention in MAG research (Chen and Bühler, 1970) since it elicits the characteristic postmating behavior in females at concentrations as low as 1 pmol (Schmidt et al., 1993). From seminal fluid, sex peptide is transported across the vaginal membrane (Lung and Wolfner, 1999) and reaches its target sites via hemolymph transport. Interestingly, one of the target sites is the neuroendocrine axis through which it stimulates JH biosynthesis by the corpora allata (Moshitzky 
et al., 1996). Through this pathway, sex peptide then controls the oogenic cycle in the ovaries (Soller et al., 1997). Sex-peptide binding sites in the mushroom bodies appear to be the anatomical correlates for the post-copulatory behavioral changes, such as the decrease in female receptivity (Fleischmann et al., 2001).

While sex peptide affects oogenesis via hormonal stimulation, Acp26Aa (ovulin) acts as a mediator of release of mature oocytes from the ovaries (Heifetz et al., 2000). Acp36DE, in turn, is a glycoprotein of $122 \mathrm{kDa}$ that is essential for sperm storage and may also control the arrangement and retention of stored sperm (Neubaum and Wolfner, 1999). Acp36DE is found associated with the wall of the oviduct, just anterior to the openings of the sperm storage organs (Bertram et al., 1996). A rather surprising finding was reported by Chapman et al. (1995), who performed mating experiments using mutant males. The accessory glands of these males produced only $1 \%$ and $3 \%$, respectively, of the secretion produced by wild type males. Females mated with males having a $3 \%$ secretory capacity exhibited a lower viability compared with the $1 \%$ males, indicating a dosedependent response. When screening the effects of ectopic Acp expression on female viability, Acp62F was identified as the villain, and subsequent analysis of its sequence and biochemical assays revealed that this protein acts as a trypsin inhibitor (Lung et al., 2002).

In other dipterans, such as Drosophila funebris, two Acps have been characterized. PS-1 is made up of 27 amino acids and is responsible for the termination of receptivity in the females (Baumann et al., 1975). PS-2 is composed of 63 amino acids that have a sequence similarity to a class of serine protease inhibitors (Schmidt et al., 1989) that may serve to delay the degradation of other bioactive peptides in the female reproductive tract. A 3990 Da peptide, OSS (ovulation stimulating substance) was identified in the accessory gland secretion of Drosophila suzukii males. Purified OSS induced ovulation and decreased receptivity when injected into Drosophila suzukii or Drosophila melanogaster females (Ohashi et al., 1991). A peptide homologous to the Drosophila melanogaster sex peptide was also isolated from Drosophila suzukii accessory glands ( $\mathrm{SP}_{\mathrm{DS}}$ of $5100 \mathrm{Da}$ ). The sex peptides isolated from the two drosophilids elicited male rejection and stimulation of oviposition after injection into the abdomen of virgin females of both species (Schmidt et al., 1993).

Biologically active MAG factors have also been purified and analyzed in other insect species. In MAG secretion from Locusta migratoria males, Lange and Loughton (1985) identified a protein of approximate $13 \mathrm{kDa}$ that promoted the oviposition of mature oocytes. In another orthopteran, Melanoplus sanguinipes, an oviposition stimulating protein (OSP) is composed of two subunits of $30 \mathrm{kDa}$, which are both necessary for its full functionality (Yi and Gillott, 1999). In female Lepidoptera, postcopulatory changes have been addressed in detail in Helicoverpa zea and H. armigera, where mating lowers the attractiveness females by decreasing their calling-pheromone synthesis. This response is triggered by chemicals in the seminal fluid, and it has been shown that injection of combined extracts of accessory glands and ejaculatory ducts blocks the synthesis of female sex pheromone (Kingan et al., 1993). The most potent component in these extracts was a $6.6 \mathrm{kDa}$ peptide (Kingan et al., 1995). Pheromone synthesis in females is regulated by pheromone biosynthesis-activating neuropeptide (PBAN), released from the brain during the scotophase (Raina, 1993). Using an in vitro preparation, Fan et al. (1999b) demonstrated that synthetic Drosophila sex peptide inhibits PBAN-induced pheromone synthesis in a dose-dependent manner, suggesting that the male factor acts directly on the pheromone gland in H. armigera. On the other hand, Drosophila SP stimulated in vitro JH biosynthesis in the corpora allata of $H$. armigera.

These observations may seem contradictory given that in $H$. armigera there is a correlation between corpus allatum activity and pheromone synthesis and release (Fan et al., 1999a). In vivo, however, the effects of a receptivityinhibiting substance on the corpus allatum and on the pheromone glands may be age-related and modulated by other factors, like PBAN. Furthermore, synthetic D. melanogaster sex peptide depressed pheromone biosynthesis in Helicoverpa armigera (Fan et al., 1999b), although the amino acid sequence of the fly peptide bears no structural similarity to the Helicoverpa peptide. The crude extracts of male accessory glands were shown to induce an earlier maturation of eggs and to stimulate 
oviposition of Helicoverpa armigera virgin females. Fractionation experiments pinned down the active factors to a proteinaceous fraction containing proteins in the 55-66 kDa range which act on female reproductive physiology, probably via JH (Jin and Gong, 2001).

Taken together, this brief and certainly incomplete overview on the structure and function of glandular products of the male reproductive tract in different insect orders gives only an idea on the complexity of this matter. Structuring this information would, however, go far beyond the purpose of this overview and, in part, has been the subject of excellent recent reviews (Wolfner, 2002; Gillott, 2003). Even after a systematization of the glandular products, a major task still lies in associating their biochemical nature and function with the reproductive strategies of the males and females in the different species and orders. Social Apidae are an interesting group to start relating structure, function and reproductive strategies because of the quite well resolved phylogeny of this group and the wide variety of mating systems, going from monandry (most stingless bees) to extreme polyandry (genus Apis).

\section{ACCESSORY GLAND PRODUCTS AND THEIR FUNCTION IN SOCIAL BEES}

A general feature in female reproductive biology in aculeate hymenopterans is the heavy investment in immature offspring. Mostly, a female produces relatively few eggs but these are laid in well protected spots and are provisioned with food stores that take them through the larval phase. From the male's perspective, such a heavy investment by the female accrues a high rate of offspring success at a relatively low investment of his own, and thus, should strongly favor mate guarding after copulation, by fending off competitors or by the production of a firm mating plug. In this context and as in other insects, mating plug components produced by accessory glands may contain bioactive compounds that manipulate the female's postcopulatory behavior and reproductive physiology.

\subsection{A cyclic dipeptide and fatty acids in bumble bees}

In social Hymenoptera, the production of a worker population precedes the production of sexuals. This will not only delay the reproductive success of the siring male(s), but may also have implications for structure-function relationships of the MAG products. The surprising findings on bioactive MAG products in bumble bees nicely illustrate this point. The mating plug that a Bombus terrestris male inserts into the bursa copulatrix after sperm transfer (Duvoisin et al., 1999) is chemically relatively simple. It contains a large amount of a cyclic dipeptide (cycloprolylproline) that is mixed to four fatty acids (palmitic, stearic, oleic and linoleic acid) turning the secretion into a highly viscous mass (Baer et al., 2000; Baer and Schmid-Hempel, 2000). The physical properties of this mating plug are thought to prevent backflow of sperm during its migration into the female's spermatheca (Duvoisin et al., 1999). The plug, however, may not necessarily serve as a physical barrier to subsequent mating attempts by bumble bee males, as a plug of the same constituents is also produced by males of B. hypnorum, and in this species, females mate multiply (Brown et al., 2002).

When testing biological activity of the mating plug components of $B$. terrestris males on a female's propensity to mate with a second male, Baer et al. (2001) Baer and SchmidHempel (2001) and Sauter et al. (2001) identified the active compound as linoleic acid in an experiment where they tested four fatty acids in the mating plug without changing its physical consistency. Equally remarkable and puzzling in this context are two questions: first, how can an apparently ubiquitous compound of relatively low specificity elicit such a major behavioral change, which when seen from the interplay between male and female reproductive interests should be under high selection pressure; and second, what does the cellular response cascade to linoleic acid look like, and how does it generate the full organismic response.

These findings clearly will need to be understood and interpreted in the context of male and female reproduction. The temperate climate bumble bees have an annual colony cycle in which gynes are produced at the end of the 
season. These mate soon after emergence, generally with one male, and thereafter enter diapause. The colony cycle starts over in the coming spring with the production of a worker population. MAG products transferred during copulation should therefore have a powerful effect only on female post copulatory behavior, preventing further copulation attempts. MAG products that could stimulate egg production, or even reduce a mated queen's longevity, as a side effect of sperm competition, would, in contrast, be highly detrimental to male fitness in such an annual colony cycle with a long reproductive diapause in the mated females.

\subsection{Multiple mating and mucus gland proteins in honey bees}

Extreme multiple mating is a hallmark of honey bee reproductive biology and sets this genus apart from all other social bees. Virgin honey bee queens realize mating flights approximately one week after they emerge from the brood cells, and within a few days after mating with 15 or more males (Adams et al., 1977; Estoup et al., 1994), they exhibit fully activated ovaries and start to lay eggs. After each copulation act, the respective drone leaves a mating sign which is easily removed by the next male. Since the mating sign left by one drone is easily removed by the next drone (Koeniger, 1986), one of the functions attributed to this plug was that it may prevent backflow of semen immediately after mating (Bishop, 1920; Woyciechowski et al., 1994). This is, however, questionable because most of the sperm injected into the oviducts is actively extruded by the queen, and only a small percentage of the mixed sperm from the different matings actually makes it into the spermatheca of an Apis mellifera queen (Ruttner, 1956). And it stands in contrast with the much lower sperm number and the higher efficiency of sperm deposition by the drones of the dwarf honey bees which have an endophallus that permits a direct injection of sperm into the spermaduct (Koeniger et al., 1990). The function of the mating sign as a residual mating plug in the multiply mating honey bees is thus questionable, and as an alternative explanation its presence was interpreted as advertising a high quality mated queen to other drones competing in the drone congregation area (Koeniger, 1990).
In a detailed comparative study on the mating signs produced and left by the drones of the different species of honey bees, Koeniger et al. (1991, 2000a) and Koeniger and Koeniger (2000) noted that males of the cavity-nesting species have particularly large mucus glands and a large bulb in their everted endophallus. In these species, the mating sign consists of the cervical plates, the bulb tube filled with coagulating mucus proteins from the mucus gland, and a smear of a sticky orange lipid secretion from the cornual glands. The mucus-filled endophallus is thought to provide a sufficiently strong connection between the flying queen and the paralyzed drone during the process of sperm transfer into the queen's oviducts, while the sticky cornual gland secretion may further strengthen the attachment and keep the mating sign in place (Koeniger et al., 1989; Koeniger and Koeniger, 2000). In contrast, the mucus glands in the dwarf honey bees are tiny and their products do not play a major role in the connection between the queen and the drone during mating, and they are only a minor component of the mating sign. In these species, the male clings to the female via its clasper-like appendix at the metatarsus and the connection is further strengthened by the sticky cornual gland secretions. The drones of the giant honey bees are intermediate, as they have a large endophallus, accompanied by elongated cornual glands and enlarged metatarsi to guarantee a strong connection while mating on the wing (Ruttner, 1975; Koeniger and Koeniger, 2000).

As mentioned above, the mating sign is a multiple component structure, requiring that mucus protein synthesis is synchronized with cornual gland activity and sperm maturation in the seminal vesicles. In Apis mellifera, the mucus glands attain full maturity during the first 9 days after emergence and their secretion changes from a fluid to viscous, slightly alkaline mucus. In sexually mature drones, this mucus immediately coagulates when in contact with air and thus, contributes to the physical stability of the mating sign (Bishop, 1920).

In view of the accumulating evidence from other insects which shows that MAG products are potent compounds that allow males to manipulate the reproductive behavior and physiology of females we started to investigate the protein composition of honey bee mucus glands and initiated a functional study. First, 
we performed a qualitative and quantitative analysis on proteins secreted by the glandular epithelium into the lumen of the mucus glands (Colonello and Hartfelder, 2003). The protein content in this secretion increases almost fifteen fold during the first five days of the adult life cycle of a honey bee drone. During this period of sexual maturation, drones do not only fully develop their flight musculature, but they also complete the maturation of sperm in their reproductive system (Mindt, 1962). In the corresponding maturation of the mucus glands, the protein pattern undergoes a reduction in complexity, and a set of three proteins with molecular masses between 43000 and 47500 becomes the dominant fraction.

This process of sexual maturation, which terminates with the initiation of mating flights, is synchronized by characteristic changes in the endocrine system of honey bee drones. The juvenile titer gradually increases (Giray and Robinson, 1996) due to an enhanced hormone synthesis by the corpora allata (Tozetto et al., 1995). Concomitantly, the ecdysteroid titer decreases markedly within the first day after emergence before it goes through a small peak around day 8 , and then, for the rest of the drone's life cycle, remains at basal levels (Colonello and Hartfelder, 2003). Based on these findings, we addressed the question as to whether and how these key hormones in insect development and reproduction may affect the maturation program of the mucus glands. We could show that injection of 20-hydroxyecdysone into newly emerged drones had a pronounced effect on mucus gland secretory activity as it essentially abolished the increase in the gland's protein content and also retarded the maturation of the MAG protein pattern. The developmental profile of the endogenous ecdysteroid titer explains the changes in protein content and pattern observed in the mucus gland of very young adult drones, and the experimental manipulation of the titer evidenced an inhibitory role for ecdysteroids in the maturation of the accessory glands of honey bee drones (Colonello and Hartfelder, 2003). Ecdysteroids and $\mathrm{JH}$, thus, appear to regulate sexual maturation process of the drones in a coordinate manner.

Little is known on the function of MAG products in honey bees, especially on the presence of bioactive compounds that may serve to stim- ulate oogenesis in newly mated queens. To assay bioactive compounds in mucus gland secretion, we designed a bioassay with virgin queens. These queens received an injection of a mucus extract into their copulation chamber and had their ovary status assessed one week later. The mucus extract was prepared by diluting the mucus contained in one gland pair in $500 \mu \mathrm{L}$ of deionized water and boiling it for 3 min to separate the coagulation proteins from heat-stable peptides, which are prime candidates for bioactive MAG compounds. After centrifugation at $10000 \mathrm{~g}$ at $4^{\circ} \mathrm{C}$ for $10 \mathrm{~min}$, the supernatants were pooled to prepare aliquots containing different gland equivalents $(1,5,10$ and 15 pairs). These were concentrated by vacuum centrifugation, adjusted with saline to a final volume of $25 \mu \mathrm{L}$ and injected into the genital cavity of 7 to 8 -days-old virgin queens by means of an insemination capillary (Camargo, 1972). Control queens received a saline injection. Injected queens were confined in plastic queen cages and were kept in nurse colonies prepared for queen rearing. After one week we assessed the survival rate and the size of 5 basal follicles per ovary as a parameter of ovary activation.

Contrary to our expectation, oogenesis (basal follicle size) was not significantly stimulated by this mucus crude extract (Wilcoxon's signed-rank test, $P>0.05$ ), and even more to our surprise, it showed an adverse effect on queen viability (Fig. 1). In fact, the bolus

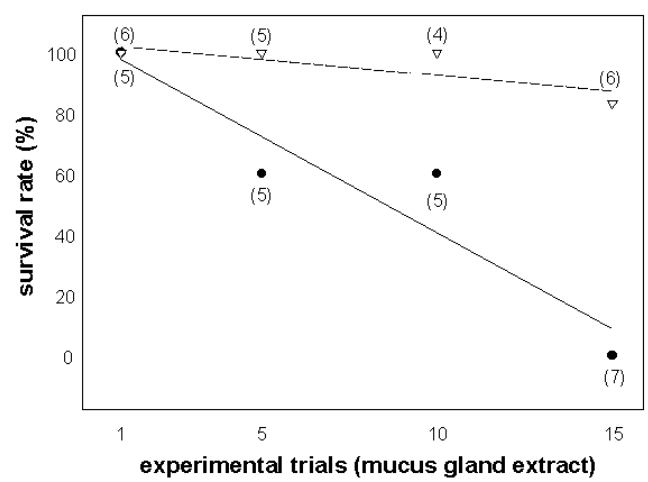

Figure 1. Toxicity of crude extract of mature honey bee drone accessory glands. Survival rate of queens injected with crude extract equivalents of $1,5,10$ or 15 gland pairs (closed circles) and of control queens injected with saline (opened triangles). The results show a clear dose-response (Pearson ProductMoment Correlation, $\mathrm{r}=0.948 ; P=0.0142)$. In parentheses, sample size. 
injection of an extract prepared from an equivalent of 15 pairs of glands turned out to be highly toxic. On closer inspection we noted that the extract-injected queens exhibited alterations in their movements (slower movements and rhythmic contractions of their abdomen, legs and antennae) already within the first hours after injection, before they died soon after. We also noted a clear dose-response for extracts prepared with increasing gland equivalents, providing even stronger evidence for the existence of MAG compounds that are toxic to queens when transferred to their bursa copulatrix. At least in these experiments, the drones' nuptial gift can be said to have become a Trojan horse, or a "Gift" in the sense of the German word.

This toxic activity in honey bee MAG secretion is reminiscent of the serine protease inhibitor (Acp62F) produced by Drosophila melangaster males. Acp62F is capable of passing from the genital cavity into hemolymph (Lung and Wolfner, 1999) and from there it interferes with essential proteolytic cascades in different tissues (Wolfner, 2002). In the honey bee we could not yet identify the protein responsible for the observed toxic action. From its general effects, however, it seems to have a strong action on the nervous system. Obviously, this does not mean that mating kills, but rather, it reveals the presence of compounds that, can be toxic when present in high concentrations. Since matings signs are inserted and removed in rapid sequence during the mating acts of the queen in the drone congregation area, and the queens returns to the colony with the mating sign of the last drone only, such toxic doses may never be reached. Rather, the biological function of these compound(s) may be to reduce the viability of microorganisms inadvertently transmitted during copulation.

Similar effects may, at least in part, also be attributed to the sticky lipids secreted by the mucus gland, the cornual glands and the bulbus. A gas chromatography analysis of the lipid secretions of these structures revealed the presence of oleic acid, as well as of linoleic and linolenic acid (G. Koeniger, personal communication). The lipid composition in the seminal fluid and mating sign, thus, appears to be quite similar to that of the bumble bees (Baer et al., 2000), but different from Bombus terrestris, there is no evidence that these fatty acids alter the behavior or physiology of a honey bee queen and prevent her from mating with other drones.

Since unsaturated fatty acids, especially linoleic acid, have antimicrobial properties against bacterial honey bee pathogens (Feldlaufer et al., 1993), it is quite plausible that the addition of such compounds to seminal fluid should significantly reduce the risk of pathogen transmission during copulation. Even though the lipids of seminal fluid have been looked at in only very few species, it is tempting to speculate that they may be rather ubiquitously transferred during mating. The question then becomes, how did linoleic acid acquire its function as an agent that changes female physiology and behavior in Bombus terrestris females so that they become refractory to males? Since this is a question of an intersexual relationship and a question of male and female fitness, this functional switch is clearly more than a simple molecular co-option.

To address the question whether lipids of the mucus glands may stimulate oogenesis in the honey bee queen, we diluted mucus secretion in acetonitrile and after centrifugation of precipitated compounds we partitioned the supernatant between saline and hexane $(1: 1, \mathrm{v}: \mathrm{v})$. The hexane phase was removed and the saline phase was reextracted with hexane. The pooled hexane phases were dried down by vacuum centrifugation and the concentrate was resuspended in $20 \mu \mathrm{L}$ saline containing $0.1 \%$ DMSO. This final volume, containing lipids of 1,5 or 10 gland pair equivalents, was injected into the genital chamber of virgin queens, as described above for peptide extracts of mucus gland secretion. Measurements of the length of basal follicles in five ovarioles per queen did not reveal any significant differences between lipid-injected versus control (saline-injected) queens, thus, largely excluding a post-mating effect for mucus gland lipids. In distinction to the peptide fraction, the lipids also did not have any short term effects on queen viability.

\subsection{No apparent accessory glands in stingless bees}

A comprehensive comparative study recently performed on the anatomy of the male reproductive system in 51 species of bees comprising six families (Ferreira et al., 2004) described 
four basic structural types. This study also fully confirmed the earlier findings on the absence of accessory glands in the male reproductive tract of Meliponini (Kerr, 1948). The spermatozoa in the male ducts are immersed in seminal fluid, which, like in the honey bee, is probably a secretory product of epithelial cells in the walls of the large seminal vesicles, and there is no evidence for other secretory cells, according to an ultrastructural analysis of the male reproductive tract in Melipona bicolor bicolor (Dallacqua and Cruz-Landim, 2003).

The lack of accessory glands sets the males of stingless bees well apart from the other families of bees. It represents a reduction in a single character while the remainder of the internal morphology of the male reproductive system of stingless bees shows a suite of conserved character states (Ferreira et al., 2004). And this conserved nature of the internal morphology also finds its parallel in the external morphology which shows a well developed genital capsule (Camargo et al., 1967).

Taxonomically, such a character combination may appear quite striking, since in the female sex the sting is completely reduced, while the same segments form a complete set of homologous appendages in the male sex. The only coincidence in this respect lies in the reduction of glands associated with the sting in the female (Abdalla et al., 2000) and the accessory glands in the male sex. In terms of developmental regulation, such character reduction resembles the block in wing disc development in worker larvae of ants. This interruption of development has recently been functionally described as a concerted shut down in the expression of defined pattern regulatory genes (Abouheif and Wray, 2002).

So, what makes up the mating sign with which a stingless bee queen returns to her colony after a mating flight, and which requires the assistance of workers to be removed from her genital chamber? It consists of the ruptured large genital capsule of the male and is, thus, quite different from the chemical plugs found in the honey bees and bumble bees. This strong mechanical plug may be one of the (proximate) reasons why queens in most species of stingless bees return single-mated from the male aggregation (Paxton et al., 1999; Peters et al., 1999). The question then becomes, are there long term effects that persist after removal of the genital capsule, preventing a queen from undergoing further mating flights and possibly even stimulating egg laying? In an experiment that varied the time of persistence of the male genital capsule in the female reproductive tract, Melo et al. (2001) could show that a one-day persistence of the plug inside the genital chamber was required before a significant stimulation of egg development was observed. The authors attributed this to a mechanical stimulation that the extensive male genital capsule may exert on the walls of the bursa copulatrix.

\subsection{General conclusions and perspectives}

When comparing knowledge on what is known about male accessory gland structure and function in bees to what is known about these subject in insects in general, the first conclusion obviously is that we have barely started to explore this field in the social Hymenoptera. The second conclusion is that the eusocial bees are extremely varied with respect to the structural and chemical composition of the mating sign. Conceptually, this may be related to several characteristics of their mating biology. The first one is the tendency for males to die during the act of mating, leaving them no options. On the side of the males, this should entail selection on a mating plug that prevents further mating by the queen. The mechanically very firm genital capsule plug left by males of stingless bees functions like a bolt that requires considerable time and effort to be removed, and thus, would serve this purpose quite well. Furthermore, the few experiments performed, so far, on stingless bees also indicate that it may manipulate the female's post-mating reproductive physiology.

In contrast, the mating sign that each honey bee drone leaves in the queen's genital chamber is quite inefficient in preventing further matings as it is easily removed by the next male that mates with the queen in the drone congregation area. In all honey bee species, the mating sign consists of a sticky lipidic secretion produced by the cornua (Koeniger et al., 1996, 2000a, b), in addition to species-specific additives, such as a proteinaceous secretion produced by the large mucus glands, the bulb and the cervical plates in the cavity-nesting Apis species. In terms of biological activity we could detect, so 
far, only a toxic effect of mucus protein(s), apparently on the queen's nervous system functions. It was quite surprising to see that the injection of a mucus extract of 15 pairs of glands literally killed queens within hours. This finding only makes sense if seen in the full context of the mating biology of honey bees, where mating plugs are quickly removed during the multiple mating attempts. The short persistence time of potentially toxic mating plug material should, thus, not interfere with the viability of the queen, even when she has mated with 15 and more drones.

Why then should drones produce compounds in their accessory glands that, at least potentially, can reduce the queen's viability? From a male perspective, this, again, only makes sense in a polyandric mating system, where such compounds are, first of all, contained inside the queen's genital tract where they may reduce the viability of sperm from other males. However, it begs the question how a male protects its own sperm against the action of, for instance, protease inhibitors such as Drosophila Acp62F. Furthermore, there is little genetic evidence in Apis mellifera for sperm competition or an advantage of being the last drone to mate with a honey bee queen (Franck et al., 2002). These recent results obtained by microsatellite analysis of workers produced by naturally mated queens contradict some of the earlier data obtained from queens that were instrumentally inseminated with mixed sperm from phenotypically different genotypes (Harbo, 1990).

It is interesting to speculate though in evolutionary terms, that mucus proteins which potentially reduce queen viability may, actually set an upper limit on the number of matings that a queen can undergo. Such a consideration would add a new facet to the much debated question of why honey bees evolved an extremely polyandric mating system (see Palmer and Oldroyd, 2000 for a compilation of the principal hypotheses) and especially, what may be its upper limits. From the queen's perspective, the addition of toxic compounds could be advantageous when these compounds exhibit antimicrobial activity, and thus help to reduce the high risk of bacterial transmission during the mating flight(s).

Bioassays performed on the complex proteinaceous mixture secreted by the mucus glands, so far, have not revealed much biological activity (other than a toxic one), leaving open the question what this mass of proteins is good for, except for a physical stabilization of the connection between the paralyzed drone and the queen during in-flight sperm transfer. We are currently carrying out a subtractive hybridization screen on mRNAs from immature versus mature glands, which, once sequenced, can be conceptually translated and submitted to local alignment comparisons against general protein sequence databanks. Candidate genes can then be selected for functional studies by RNA interference (Amdam et al., 2003) to specifically eliminate defined proteins from the gland's products.

Knowledge on the mating biology of bumble bees has attained maturity in the last years (Baer, 2003; Baer et al., 2003) and, in fact, Bombus terrestris now represents one of the best studied systems on mating plug chemistry and function. What is surprising is not only the low complexity in the chemical composition of the mating plug, but also the fact that a rather non-specific fatty acid, that appears to be a major constituent of the lipid secretion of the male reproductive tract in bees in general, turned out to be the main player in the manipulation of female reproductive behavior. As already mentioned, part of this low complexity may be attributed to the long delay between mating and the initiation of egg laying and colony formation which essentially rules out and would select against the production of ovary stimulation factors.

To our view, there are two main open questions with respect to mating plug compounds in bumble bees. The first is their glandular origin. So far, the studies have primarily defined the nature of the mating plug and paid little attention to its glandular source(s). It will be of particular interest to pin down the exact production and secretion site for the fatty acids. The second question concerns the mode action of linoleic acid on female behavior. At present, we cannot do more than speculate that linoleic acid actually might act as a protein-activating lipid, similar to a mode of action that has recently been proposed for juvenile hormone (Wheeler and Nijhout, 2003). This would at least explain the ease with which this apparently ubiquitous compound in mating signs of bees has become integrated into a signaling system 
for behavioral and physiological changes in female reproduction.

The reduction of accessory glands in the reproductive ducts of stingless bees is another striking observation. Again, we can see two questions of interest in this system. The first one is a proximate one; that is, what is the chemical composition of the seminal fluid and of the mating plug? Does it contain lipids and proteins or is it mainly a carbohydrate-rich secretion from the seminal vesicles? The second question concerns ultimate reasons for the reduction of these glands in a basically monandric mating strategy, This is particularly interesting when considering the generally conserved morphology of the internal reproductive tract and of the external genitals of stingless bee males.

A trend to a reduction of accessory glands has recently been demonstrated in attine ants (Baer and Boomsma, 2004; Mikheyev, 2004), where it was considered as a decreased investment in a mating plug in favor of an increased investment in sperm number for sperm competition. However, in the highly eusocial bees, the trend is exactly the opposite, with large accessory glands in the extremely polyandric genus Apis and completely reduced glands in the monandric stingless bees, showing that the association of large or small accessory glands with single or multiple mating is an oversimplification of the problem. In conclusion, a complete understanding of the functional significance of the mating plug (mating sign) and its constituents in social insects requires a multifactorial analysis which should include information on phylogeny, from analytical biochemistry and genomics, on the morphology of the genital tract, on offspring genotype (evidence for sperm competition), and, especially, detailed data on mating biology. The latter is not trivial in terms of structural requirements, and in the highly eusocial bees there are tremendous differences as to where mating takes place (on the wing in a drone congregation area or on the ground near the nest), how and how much sperm is transferred, and what is the postmating reaction of females.

\section{ACKNOWLEDGEMENTS}

We thank Gudrun Koeniger for her comments and very generous access to unpublished data. The comments received from João M.F. Camargo and two anonymous referees also made us review (and hopefully correct) several simplistic assumptions. Experimental studies on mucus gland proteins and lipids in Apis mellifera received funding from the Fundação de Amparo à Pesquisa do Estado de São Paulo (FAPESP, grants \# 1999/00719-6 and 02/ 06671-0).

Résumé - C'est mon type de femme - Les produits de sécrétion des glandes accessoires mâles et leur fonction dans la biologie de la reproduction chez les abeilles sociales. Les glandes accessoires mâles des insectes (MAG) produisent une variété de composés, dont des acides aminés, des amines biogènes, des protéines, des hydrates de carbone et des lipides. Leurs sécrétions ont deux fonctions principales : la première, qui est probablement l'originelle, sert à aider le transfert de sperme (spermatophore ou fluide séminal); la seconde consiste à s'assurer que le mâle a l'exclusivité de la paternité après accouplement avec une femelle. On a en effet montré chez de nombreux insectes que les composés des MAG manipulaient le comportement reproducteur et la physiologie de la reproduction en réduisant la réceptivité et en stimulant la production d'œufs et la ponte. Certains composés des MAG peuvent en outre contribuer à réduire la longévité de la femelle. Les différents niveaux de socialité et la large gamme de stratégies d'accouplement font des abeilles une base d'étude intéressante pour les produits des MAG et leurs fonctions supposées. Chez le bourdon terrestre, Bombus terrestris, on a montré que les lipides présents dans le bouchon d'accouplement, en particulier l'acide linoléique, empêchaient les reines de subir d'autres tentatives d'accouplement. Chez le genre Apis, le signe de fécondation est une structure hautement complexe constituée du bulbe de l'endophallus, des plaques cervicales et aussi de mucus coagulé et de la sécrétion collante des cornes. Les glandes à mucus des mâles d'Apis mellifera synthétisent de grandes quantités de protéines au cours de la maturation sexuelle. Les glandes des mâles qui viennent de naître sécrètent un mélange complexe de protéines, qui se transforme peu à peu en un ensemble réduit dans lequel dominent les protéines de poids moléculaire compris entre 43 et $47,5 \mathrm{kDa}$. Le système endocrinien joue un rôle majeur dans le contrôle du processus de maturation de la synthèse des protéines des MAG, avec présence d'ecdystéroïdes qui agissent comme régulateurs négatifs. Les recherches sur l'activité biologique des extraits de MAG de l'Abeille domestique n'ont révélé jusqu'à ce jour que des composés protéiniques potentiellement toxiques. En liaison avec les lipides apparemment omniprésents des sécrétions des MAG, ces protéines peuvent aider à réduire la transmission de bactéries au cours des accouplements qui s'ensuivent. Les glandes accessoires mâles sont absentes du système reproducteur chez les abeilles sans aiguillon, généralement monandres, et il a été suggéré que la 
capsule génitale du mâle qui reste dans le tractus femelle après l'accouplement pourrait servir de stimulus mécanique pour stimuler l'ovogenèse et la ponte.

Apis / Bombus / Meliponini / appareil reproducteur / signe de fécondation

Zusammenfassung - Sie ist mein Mädchen - die Produkte der akzessorischen Drüsen der Männchen und ihre Funktion in der Paarungsbiologie sozialer Bienen. Die akzessorischen Drüsen (MAGs) im Genitaltrakt von Insektenmännchen produzieren eine Mischung verschiedener Komponenten, bestehend aus Aminosäuren und biogenen Aminen, Proteinen, Kohlenhydraten und Lipiden. Ihre Sekretionsprodukte erfüllen zwei Funktionen. Die erste und vermutlich ursprüngliche Funktion liegt in der Beihilfe zur Spermaübertagung, als Komponenten der Spermatophore oder Samenflüssigkeit. Sekundär spielen MAG Produkte eine Rolle in der Sicherung der Vaterschaft, denn bei vielen Insekten manipulieren sie das Fortpflanzungsverhalten und die Reproduktionsphysiologie der Weibchen, indem sie die Reziptivität der Weibchen mindern und sie zur Eiproduktion und Eiablage stimulieren. Darüberhinaus können einige der MAGProdukte die Lebenspanne der Weibchen mindern. Aufgrund ihres Spektrums sozialer Organisation und einer breiten Variation in den jeweiligen Paarungsstrategien stellen soziale Bienen ein interessantes Material für die Untersuchung von MAGProdukten und ihrer Funktion dar. Bei der Hummel, Bombus terrestris führen Fettsäuren, insbesondere Linolsäure, im Begattungszeichen dazu, dass die Königin keine weiteren Paarungsversuche unternimmt. In der Gattung Apis, insbesondere bei den höhlenbrütenden Arten und den Riesenhonigbienen, ist das Begattungszeichen eine hochkomplexe Struktur, bestehend aus dem Bulbus des Endophallus, den Cervicalplatten, sowie dem koagulierten Mucussekret und dem klebrigen Sekret der Cornualdrüsen. Die Mucusdrüsen der Drohnen von Apis mellifera produzieren eine enorme Menge an sekretorischen Proteinen und während der Geschlechtsreifung bildet sich ein zunehmend Proteinmuster heraus, in dem Proteine mit 43-47,5 kDa dominieren. Das endokrine System spielt eine wichtige Rolle in der Kontrolle dieses Reifungsprozesses, wobei Ecdysteroide als Reifungshemmer wirken. Untersuchungen zur biologischen Aktivität der MAG-Produkte bei Königinnen haben bisher nur die Existenz potentiell toxischer Komponenten aufzeigen können. Zusammen mit den Fettsäuren, die offensichtlich ubiquitär in MAG-Sekreten der Bienen vorkommen, könnten diese Proteine dazu beitragen, die Gefahr der Übertragung von Bakterien während der aufeinanderfolgenden Paarungen $\mathrm{zu}$ reduzieren. Im Genitaltrakt der überwiegend monandrischen stachellosen Bienen sind keine akzessorischen Drüsen zu finden, und das Begat- tungszeichen besteht im wesentlichen aus der Genitalkapsel des Drohns. Bisherige Ergebnisse weisen darauf hin, dass dieses nach der Paarung verbleibende Begattungszeichen zu einer mechanischen Reizung im weiblichen Genitaltrakt führt und damit die Oogenese und Eiablage stimuliert.

Honigbiene / Hummel / Meliponini / Reproduktionstrakt / Paarungszeichen / Apis / Bombus

\section{REFERENCES}

Abdalla H.C., Cruz-Landim C., Zucchi R. (2000) Why some meliponinae workers do not have a Dufour gland? XVIII Int. Congr. Zool., Athens, Greece, p. 168.

Abouheif E., Wray G.A. (2002) Evolution of the genetic network underlying wing polyphenism in ants, Science 297, 249-252.

Adams J., Rothman E., Kerr W.E., Paulino Z.L. (1977) Estimation of the number of sex alleles and queen mating from diploid male frequencies in a population of Apis mellifera, Genetics 86, 583-596.

Amdam G.V., Simões Z.L.P., Guidugli K.R., Norberg K., Omholt S.W. (2003) Disruption of vitellogenin gene function in adult honeybees by intraabdominal injection of double-stranded RNA, BMC Biotechnol. 3, 8 p., available online: http://www.biomedcentral.com/1472-6750/3/1 (accessed on 24 February 2005).

Baer B. (2003) Bumblebees as model organisms to study male sexual selection in social insects, Behav. Ecol. Sociobiol. 54, 521-533.

Baer B., Schmid-Hempel P. (2000) The artificial insemination of bumblebee queens, Insectes Soc. 47, 183-187.

Baer B., Schmid-Hempel P. (2001) Unexpected consequences of polyandry for parasitism and fitness in the bumblebee, Bombus terrestris, Evolution 55, 1639-1643.

Baer B., Boomsma J.J. (2004) Male reproductive investment and queen mating-frequency in fungus-growing ants, Behav. Ecol. 15, 426-432.

Baer B., Maile R., Schmid-Hempel P., Morgan E.D., Jones G.R. (2000) Chemistry of a mating plug in bumblebees, J. Chem. Ecol. 26, 1869-1875.

Baer B., Morgan E.D., Schmid-Hempel P. (2001) A nonspecific fatty acid within the bumblebee mating plug prevents females from remating, Proc. Natl. Acad. Sci. USA 98, 3926-3928.

Baer B., Schmid-Hempel P., Hoeg J.T., Boomsma J.J. (2003) Sperm length, sperm storage and mating system characteristics in bumblebees, Insectes Soc. 50, 101-108.

Baumann H., Wilson K.J., Chen P.S., Humbel R.E. (1975) Amino acid sequence of a peptide (PS-1) from Drosophila funebris - paragonial peptide from males which reduces receptivity of female, Eur. J. Biochem. 52, 521-529. 
Bertram M.J., Neubaum D.M., Wolfner M.F. (1996) Localization of the Drosophila male accessory gland protein Acp36DE in the mated female suggests a role in sperm storage, Insect Biochem. Mol. Biol. 26, 971-980.

Bishop G.H. (1920) Fertilization in the honeybee. I. The male sexual organs: their histological structure and physiological functioning, J. Exp. Zool. 31, 225-265.

Blum M.S., Hilker M. (2002) Chemical protection of insect eggs, in: Hilker M., Meiners T. (Eds.), Chemoecology of Insect Eggs and Egg Deposition, Blackwell, Berlin, pp. 61-90.

Borovsky D., Carlson D.A., Hancock R.G., Rembold H., Van Handel E. (1994) De novo biosynthesis of juvenile hormone-III and hormone-I by the accessory glands of the male mosquito, Insect Biochem. Mol. Biol. 24, 437-444.

Brown M.J.F., Baer B., Schmid-Hempel R., SchmidHempel P. (2002) Dynamics of multiple-mating in the bumble bee Bombus hypnorum, Insectes Soc. 49, 315-319.

Camargo J.M.F. (1972) Manual de Apicultura Editora Agronômica Ceres, São Paulo, p. 252.

Camargo J.M.F., Kerr W.E., Lopes C.R. (1967) Morfologia externa de Melipona (Melipona) marginata Lepeletier (Hymenoptera, Apoidea), Pap. Avul. Zool., Sao Paulo 20, 229-258.

Chapman T. (2001) Seminal fluid - mediated fitness traits in Drosophila, Heredity 87, 511-521.

Chapman T., Liddle L.F., Kalb J.M., Wolfner M.F., Partridge L. (1995) Cost of mating in Drosophila melanogaster females is mediated by male accessory gland products, Nature 373, 241-244.

Chen P.S., Bühler R. (1970) Paragonial substance (sex-peptide) and other free ninhydrin positive components in male and female adults of Drosophila melanogaster, J. Insect Physiol. 16, 615-627.

Chen P.S., Stumm-Zollinger E., Aigaki T., Balmer J., Bienz M., Bohlen P. (1988) A male accessory gland peptide that regulates reproductive behavior of female Drosophila melanogaster, Cell 54, 291-298.

Colonello N.A., Hartfelder K. (2003) Protein content and pattern during mucus gland maturation and its ecdysteroid control in honey bee drones, Apidologie 34, 257-267.

Dallacqua R.P., Cruz-Landim C. (2003) Ultrastructure of the ducts of the reproductive tract of males of Melipona bicolor bicolor Lepeletier (Hymenoptera, Apinae, Meliponini), Anat. Histol. Embryol. 32, 276-281.

Davey K.G. (1965) Copulation and egg production in Rhodnius prolixus - role of spermathecae, J. Exp. Biol. 42, 373-378.

Duvoisin N., Baer B., Schmid-Hempel P. (1999) Sperm transfer and male competition in a bumblebee, Anim. Behav. 58, 743-749.

Eisner T., Rossini C., González A., Iyengar V.K., Siegler M.V.S., Smedley S.R. (2002) Paternal investment in egg defense, in: Hilker M., Meiners
T. (Eds.), Chemoecology of Insect Eggs and Egg Deposition, Blackwell, Berlin, pp. 91-116.

Estoup A., Solignac M., Cornuet J.M. (1994) Precise assessment of the number of patrilines and of genetic relatedness in honeybee colonies, Proc. R. Soc. Lond. B 258, 1-7.

Fan Y.L., Rafaeli A., Gileadi C., Applebaum S.W. (1999a) Juvenile hormone induction of pheromone gland PBAN-responsiveness in Helicoverpa armigera females, Insect Biochem. Mol. Biol. 29, 635-641.

Fan Y.L., Rafaeli A., Gileadi C., Kubli E., Applebaum S.W. (1999b) Drosophila melanogaster sex peptide stimulates juvenile hormone synthesis and depresses sex pheromone production in Helicoverpa armigera, J. Insect Physiol. 45, 127-133.

Feldlaufer M.F., Lusby W.R., Knox D.A., Shimanuki H. (1993) Isolation and identification of linoleic acid as an antimicrobial agent from the chalkbrood fungus, Ascosphaera apis, Apidologie 24, 89-94.

Ferreira A., Abdalla F.C., Kerr W.E., Cruz-Landim C. (2004) Systematics, morphology and physiology - comparative anatomy of the male reproductive internal organs of 51 species of bees, Neotrop. Entomol. 33, 569-576.

Fleischmann I., Cotton B., Choffat Y., Spengler M., Kubli E. (2001) Mushroom bodies and post mating behaviors of Drosophila melanogaster females, J. Neurogenet. 15, 1-27.

Franck P., Solignac M., Vautrin D., Cornuet J.-M., Koeniger G., Koeniger N. (2002) Sperm competition and last male-precendence in the honey bee, Anim. Behav. 64, 503-509.

Friedel T., Gillott C. (1976) Male accessory gland substance of Melanoplus sanguinipes: an oviposition stimulant under the control of the corpus allatum, J. Insect Physiol. 22, 489-495.

Gillott C. (1988) Arthropoda-Insecta, in: Reproductive Biology of Invertebrates, Adiyodi K.G., Adiyodi R.G. (Eds.), Wiley, Chichester, Vol. 3, pp. 319-471.

Gillot C. (1996) Male accessory glands: functions and control of secretory activity, Invertebr. Reprod. Dev. 30, 1999-2005.

Gillott C. (2003) Male accessory gland secretions: modulators of female reproductive physiology and behavior, Annu. Rev. Entomol. 48, 163184.

Giray T., Robinson G.E. (1996) Common endocrine and genetic mechanisms of behavioral development in male and worker honey bees and the evolution of division of labor, Proc. Natl. Acad. Sci. USA 93, 11718-11722.

Happ G.M. (1992) Maturation of the male reproductive system and its endocrine regulation, Annu. Rev. Entomol. 37, 303-320.

Harbo J.R. (1990) Artificial mixing of spermatozoa from honeybees and evidence for sperm competition, J. Apic. Res. 29, 151-158.

Heifetz Y., Lung O., Frongillo E.A., Wolfner M.F. (2000) The Drosophila seminal fluid protein 
Acp26Aa stimulates release of oocytes by the ovary, Curr. Biol. 10, 99-102.

Ismail P.M., Gillot C. (1995) 20-Hydroxyecdysone and juvenile hormone regulation of specific protein synthesis in the male accessory reproductive gland of Melanoplus sanguinipes under in vitro conditions, J. Insect Physiol. 41, 911-920.

Jin Z.Y., Gong H. (2001) Male accessory gland derived factors can stimulate oogenesis and enhance oviposition in Helicoverpa armigera (Lepidoptera: Noctuidae), Arch. Insect Biochem. Physiol. 46, 175-185.

Kalb J.M., Di Benedetto A.J., Wolfner M.F. (1993) Probing the function of Drosophila melanogaster accessory glands by directed cell ablation, Proc. Natl. Acad. Sci. USA 90, 8093-8097.

Kerr W.E. (1948) Estudos sobre o gênero Melipona, Anais Esc. Super. Agr. "Luiz de Queiroz" 5, 181276.

Kingan T.G., Thomas-Laemont P.A., Raina A.K. (1993) Male accessory gland factors elicit change from virgin to mated behavior in the female corn earworm moth Helicoverpa zea, J. Exp. Biol. 183, 61-76.

Kingan T.G., Bodnar W.M., Raina A.K., Shabanowitz J., Hunt D.F. (1995) The loss of female sex pheromone after mating in the corn earworm moth Helicoverpa zea -identification of a male pheromonostatic peptide, Proc. Natl. Acad. Sci. USA 92, 5082-5086.

Koeniger G. (1986) Mating sign and multiple mating in the honeybee, Bee World 67, 141-150.

Koeniger G. (1990) The role of the mating sign in honey bees Apis mellifera L.: does it hinder or promote multiple mating? Anim. Behav. 39, 444449.

Koeniger N., Koeniger G. (2000) Reproductive isolation among species of the genus Apis, Apidologie 31, 313-339.

Koeniger N., Koeniger G., Wongsiri S. (1989) Mating and sperm transfer in Apis florea, Apidologie 20, 413-418.

Koeniger G., Koeniger N., Mardan M., Punchihewa R.W.K., Otis G.W. (1990) Numbers of spermatozoa in queens and drones indicate multiple mating in Apis andreniformis and Apis dorsata, Apidologie 21, 181-186.

Koeniger G., Koeniger N., Mardan M., Otis G.W., Wongsiri S. (1991) Comparative anatomy of male genital organs in the genus Apis, Apidologie $23,539-552$.

Koeniger G., Hänel H., Wissel M., Herth W. (1996) The cornual gland of the honey bee drone (Apis mellifera L.): structure and secretion, Apidologie $28,145-156$.

Koeniger G., Koeniger N., Tingek S. (2000a) Diversity of the mating sign and its function in the genus Apis, 7th Int. Congr. on Tropical Bees: Management and Diversity, Chiang Mai, Thailand, IBRA.

Koeniger G., Koeniger N., Tingek S., Kelitu A. (2000b) Mating flights and sperm transfer in the dwarf honeybee, Apis andreniformis (Smith, 1858), Apidologie 31, 301-311.

Lange A.B., Loughton B.G. (1985) An oviposition stimulating factor in the male accessory reproductive gland of the locust, Locusta migratoria, Gen. Comp. Endocrinol. 57, 208-215.

Leopold R.A. (1976) The role of male accessory glands in insect reproduction, Annu. Rev. Entomol. 21, 199-221.

Lung O., Wolfner M.F. (1999) Drosophila seminal fluid proteins enter the circulatory system of the mated female fly by crossing the posterior vaginal wall, Insect Biochem. Mol. Biol. 29, 1043-1052.

Lung O., Tram U., Finnerty C.M., Eipper-Mains M.A., Kalb J.M., Wolfner M.F. (2002) The Drosophila melanogaster seminal fluid protein Acp62F is a protease inhibitor that is toxic upon ectopic expression, Genetics 160, 211-224.

Melo G.A.R., Buschini M.L.T., Campos L.A.O. (2001) Ovarian activation in Melipona quadrifasciata queens is triggered by mating plug stimulation, Apidologie 32, 355-361.

Mikheyev A.S. (2004) Male accessory gland size and the evolutionary transition from single to multiple mating in the fungus-gardening ants, J. Insect Sci. 4, 37, http://www.insectscience.org/ 4.37 (accessed on 24 February 2005).

Mindt B. (1962) Untersuchungen über das Leben der Drohnen, insbesondere Ernährung und Geschlechtsreife, Z. Bienenforsch. 6, 9-33.

Morrison P.E., Venkatesh K., Thompson B. (1982) The role of male accessory gland substance on female reproduction with some observations of spermatogenesis in the stable fly, J. Insect Physiol. 28, 607-614.

Moshitzky P., Fleischmann I., Chaimov N., Saudan P., Klauser S., Kubli E., Applebaum S.W. (1996) Sex-peptide activates juvenile hormone biosynthesis in the Drosophila melanogaster corpus allatum, Arch. Insect Biochem. Physiol. $32,363-374$.

Neubaum D.M., Wolfner M.F. (1999) Mated Drosophila melanogaster females require a seminal fluid protein, Acp36DE, to store sperm efficiently, Genetics 153, 845-857.

Ohashi Y.Y., Hainofukushima K., Fuyama Y. (1991) Purification and characterization of an ovulation stimulating substance from the male accessory glands of Drosophila suzukii, Insect Biochem. 21, 413-419.

Palmer K.A., Oldroyd B.P. (2000) Evolution of multiple mating in the genus Apis, Apidologie 31, 235-248.

Paxton R.J., Weisschuh N., Engels W., Hartfelder K., Quezada-Euan J.J.G. (1999) Not only single mating in stingless bees, Naturwissenschaften 86 , 143-146.

Peters J.M., Queller D.C., Imperatriz-Fonseca V.L., Roubik D.W., Strassmann J.E. (1999) Mate number, kin selection and social conflicts in stingless bees and honeybees, Proc. R. Soc. Lond. B 266, 379-384. 
Pickford R., Ewen A.B., Gillott C. (1969) Male accessory gland substance; an egg-laying stimulant in Melanoplus sanguinipes $(\mathrm{F})$ (Orthoptera - Acrididae), Can. J. Zool. 47, 11991203.

Raina A.K. (1993) Neuroendocrine control of sexpheromone biosynthesis in Lepidoptera, Annu. Rev. Entomol. 38, 329-349.

Ruttner F. (1956) Zur Frage der Spermaübertragung bei der Bienenkönigin, Insectes Soc. 3, 351-359.

Ruttner F. (1975) Ein metarsaler Haftapparat bei den Drohnen der Gattung Apis (Hymenoptera), Entomol. Gen. 2, 22-29.

Sauter A., Brown M.J.F., Baer B., Schmid-Hempel P. (2001) Males of social insects can prevent queens from multiple mating, Proc. R. Soc. Lond. B 268, 1449-1454.

Schmidt T., Stumm-Zollinger E., Chen P.S., Bohlen P., Stone S.R. (1989) A male accessory gland peptide with protease inhibitory activity in Drosophila funebris, J. Biol. Chem. 264, 97459749.

Schmidt T., Choffat Y., Klauser S., Kubli E. (1993) The Drosophila melanogaster sex-peptide - a molecular analysis of structure-function relationships, J. Insect Physiol. 39, 361-368.

Shirk P.D., Bhaskaran G., Roller H. (1980) The transfer of juvenile hormone from male to female during mating in the cecropia silkmoth, Experientia 36, 682-683.

Soller M., Bownes M., Kubli E. (1997) Mating and sex-peptide stimulate the accumulation of yolk in oocytes of Drosophila melanogaster, Eur. J. Biochem. 243, 732-738.
Tozetto S.O., Rachinsky A., Engels W. (1995) Reactivation of juvenile hormone synthesis in adult drones of the honey bee, Apis mellifera carnica, Experientia 51, 945-946.

Wheeler D.E., Nijhout H.F. (2003) A perspective for understanding the modes of $\mathrm{JH}$ action as a lipid signaling system, Bioessays 25, 994-1001.

Wolfner M.F. (1997) Tokens of love: functions and regulation of Drosophila male accessory gland products, Insect Biochem. Mol. Biol. 27, 179 192.

Wolfner M.F. (2002) The gifts that keep on giving: physiological functions and evolutionary dynamics of male seminal proteins in Drosophila, Heredity 88, 85-93.

Wolfner M.F., Harada H.A., Bertram M.J., Stelick T.J., Kraus K.W., Kalb J.M., Lung Y.O., Neubaum D.M., Park M., Tram U. (1997) New genes for male accessory gland proteins in Drosophila melanogaster, Insect Biochem. Mol. Biol. 27, 825-834.

Woyciechowski M., Kabat L., Krol E. (1994) The function of the mating sign in honeybees, Apis mellifera $\mathrm{L}$ - new evidence, Anim. Behav. 47 $733-735$

Woyke J. (1956) Anatomo-physiological changes in queen-bees returning from mating flights, and the process of multiple mating, Bull. Acad. Polon. Sci. 4, 81-87.

Yi S.X., Gillott C. (1999) Purification and characterization of an oviposition-stimulating protein of the long hyaline tubules in the male migratory grasshopper, Melanoplus sanguinipes, J. Insect Physiol. $45,143-150$. 